\title{
In vitro antiproliferative/cytotoxic activity on cancer cell lines of a cardanol and a cardol enriched from Thai Apis mellifera propolis
}

Dungporn Teerasripreecha', Preecha Phuwapraisirisan², Songchan Puthong ${ }^{3}$, Kiyoshi Kimura ${ }^{4}$, Masayuki Okuyama ${ }^{5}$, Haruhide Mori ${ }^{5}$, Atsuo Kimura ${ }^{5}$ and Chanpen Chanchao ${ }^{1,6^{*}}$

\begin{abstract}
Background: Propolis is a complex resinous honeybee product. It is reported to display diverse bioactivities, such as antimicrobial, anti-inflammatory and anti-tumor properties, which are mainly due to phenolic compounds, and especially flavonoids. The diversity of bioactive compounds depends on the geography and climate, since these factors affect the floral diversity. Here, Apis mellifera propolis from Nan province, Thailand, was evaluated for potential anti-cancer activity.
\end{abstract}

Methods: Propolis was sequentially extracted with methanol, dichloromethane and hexane and the cytotoxic activity of each crude extract was assayed for antiproliferative/cytotoxic activity in vitro against five human cell lines derived from duet carcinoma (BT474), undifferentiated lung (Chaco), liver hepatoblastoma (Hep-G2), gastric carcinoma (KATO-III) and colon adenocarcinoma (SW620) cancers. The human foreskin fibroblast cell line (Hs27) was used as a non-transformed control. Those crude extracts that displayed antiproliferative/cytotoxic activity were then further fractionated by column chromatography using TLC-pattern and MTT-cytotoxicity bioassay guided selection of the fractions. The chemical structure of each enriched bioactive compound was analyzed by nuclear magnetic resonance and mass spectroscopy.

Results: The crude hexane and dichloromethane extracts of propolis displayed antiproliferative/cytotoxic activities with $\mathrm{IC}_{50}$ values across the five cancer cell lines ranging from 41.3 to $52.4 \mu \mathrm{g} / \mathrm{ml}$ and from 43.8 to $53.5 \mu \mathrm{g} / \mathrm{ml}$, respectively. Two main bioactive components were isolated, one cardanol and one cardol, with broadly similar in vitro antiproliferation/cytotoxicity $\mathrm{IC}_{50}$ values across the five cancer cell lines and the control Hs27 cell line, ranging from 10.8 to $29.3 \mu \mathrm{g} / \mathrm{ml}$ for the cardanol and < 3.13 to $5.97 \mu \mathrm{g} / \mathrm{ml}(6.82$ - $13.0 \mu \mathrm{M})$ for the cardol. Moreover, both compounds induced cytotoxicity and cell death without DNA fragmentation in the cancer cells, but only an antiproliferation response in the control Hs27 cells However, these two compounds did not account for the net antiproliferation/cytotoxic activity of the crude extracts suggesting the existence of other potent compounds or synergistic interactions in the propolis extracts.

Conclusion: This is the first report that Thai $A$. mellifera propolis contains at least two potentially new compounds (a cardanol and a cardol) with potential anti-cancer bioactivity. Both could be alternative antiproliferative agents for future development as anti-cancer drugs.

Keywords: Antiproliferative activity, Apis mellifera, Propolis, Cancer cell, Cardanol, Cardol

\footnotetext{
* Correspondence: chanpen@sc.chula.ac.th

'Department of Biology, Faculty of Science, Chulalongkorn University, 254

Phayathai Road, Bangkok 10330, Thailand

Full list of author information is available at the end of the article
} 


\section{Background}

Propolis is a sticky resin produced by various bee species and is mainly derived from the resins collected by bees from the buds and barks of trees [1]. It is used for the construction and repair of hives [2] and is considered to act as a protective barrier against contaminating microorganisms [3]. Propolis from various geographical locations, bee species and seasons, as well as their extracts, have been reported to exhibit a diverse array of bioactivities, such as antibacterial [4], antifungal [5], antiparasitic [6], free radical scavenging [7], anti-inflammatory [8] and antiproliferative [9] activities. Due to the broad range of bioactivities ascribed to propolis, it has long been used in traditional medicine [10]. Furthermore, at present, propolis is deemed to be acceptable for use in foods, such as beverages, health foods and nutritional supplements, as well as in cosmetics and personal hygiene products like toothpaste and soap.

Propolis typically consists of resin and balsam (50\%), wax (30\%), oil (10\%), pollen (5\%) and other (5\%) minor components [11]. The main bioactive chemical compounds in propolis are reported to be phenolic acid, terpenes, cinnamic acid, caffeic acid, several esters and flavonoids, the last of which includes flavones, flavanones, flavonols, dihydroflavonols and chalcones $[12,13]$. However, the chemical composition of propolis is qualitatively and quantitatively variable, depending on the available floral diversity at the location, the bee species and the season of collection $[14,15]$. Because the diverse array and types of chemical components in propolis vary in size and polarity, the solvents used to extract the propolis play a key role in the bioactivities, including anti-cancer activities, that are obtained in the crude extracts or subsequent fractions [16], due to the differential fractionation of components between different extracting solvents. In addition to organic solvents, edible vegetable oils, triglycerides and fatty acids have been used to extract propolis [9]. Given that bioactivity guided fractionation processes are commonly used to meet the logistic demands of enriching such a complex mixture of components, it is important to note that different cell lines have been reported to vary in their sensitivity to each of the different bioactive compounds isolated from propolis. Regardless, caffeic acid phenethyl ester (CAPE) currently seems to be the most interesting component isolated from propolis and is currently being developed as a potential anti-cancer drug since it can inhibit the in vitro growth of many cell lines [17] including the estrogen receptor positive $\left(E R^{+}\right)$and negative (ER ${ }^{-}$MCF7 and MDA231 cell lines, respectively [18], along with the chemoresistant PANC-1 cell line [19]. The mechanism of how CAPE inhibits the growth of cancer cell lines has been widely studied. In addition,
CAPE has been reported to only be cytotoxic to cancer cell lines and not to normal cells in vitro [20,21], and this is additionally supported by the results from the systemic in vivo administration of CAPE [22]. Other than CAPE, artepillin $\mathrm{C}$ from Brazilian green propolis was reported to almost completely suppress the growth of human neurofibromatosis tumor xenografts in mice by blocking the oncogenic PAK1 signaling pathway [23]. Furthermore, the oil extract of Brazilian propolis, of which the significant bioactive compound is artepillin $\mathrm{C}$, could effectively inhibit sarcoma 180 ascites tumor cells in male Swiss mice [9].

In contrast to Western medicine, traditional folklore based Eastern medicine is generally based upon the use of extracts from natural sources that consist of multiple components. Although their effects are not acute or their side effect(s) can be delayed, their chronic usage can result in the gradual accumulation of toxic compounds [24]. For example, with respect to propolis it has been shown that two caffeic acid esters in poplar propolis, prenyl caffeate isomers and phenylethyl caffeate, can act as allergens and sensitize individuals [25]. Thus, minimizing the allergen content in propolis or its extracts is important [26]. In contrast, although pure chemicals are used in Western medicine, which then avoids this type of problem along with antagonistic or undesired (non-intended) side affects, their effects are acute and side effects, especially the selection for chemoresistant cancers and antibiotic-resistant bacteria, are still highly problematical. Thus, it is important to find new classes of agents, such as those with different target sites or modes of action, in order to relieve this problem.

In this research, we aimed to isolate compounds with anti-proliferative/cytotoxic activities against human cancer cells from A. mellifera propolis collected from within the Nan province in Northern Thailand. Propolis was extracted sequentially with three solvents of decreasing polarity, and the crude extracts screened for antiproliferative/cytotoxic activity against five human cancer cell lines using the 3- (4, 5-dimethyl-thiazol-2-yl) 2, 5-diphenyl-tetrazolium bromide (MTT) assay. The crude propolis extract that displayed significant antiproliferative/ cytotoxic activity was then further fractionated by column chromatography, using thin layer chromatography (TLC) pattern profiling and MTT bioassay guided selection of the fractions. The apparently pure bioactive fractions were then characterized for their formula structure by nuclear magnetic resonance (NMR) and electrospray ionization mass spectrometry (EIS-MS), whilst their in vitro cytotoxicity against the five human cancer cell lines was evaluated in comparison to a non-transformed (normal) human cell line using the MTT assay and 
assaying the cell morphology in tissue culture and DNA fragmentation pattern.

\section{Methods}

\section{Propolis collection}

Propolis of Apis mellifera was collected from an apiary in Pua district, Nan province, Thailand, during January 28 - February 1, 2010. It was kept in the dark by wrapping with aluminium foil until used.

\section{Bioassay-guided isolation (partition)}

The extraction procedure essentially followed that reported by Umthong et al. [27] and Najafi et al. [28]. Propolis (90 g) was stirred with $400 \mathrm{ml}$ of $80 \%$ (v/v) methanol $(\mathrm{MeOH})$ at $100 \mathrm{rpm}, 15^{\circ} \mathrm{C}$ for $18 \mathrm{~h}$ and then clarified by centrifugation at 7,000 rpm, $20^{\circ} \mathrm{C}$ for 15 min. The extract (supernatant) was harvested and the solvent removed by low pressure evaporation to leave the crude $\mathrm{MeOH}$ extract of propolis (CME). The residual propolis (pellet) was then sequentially extracted in the same way with $400 \mathrm{ml}$ of dichloromethane $\left(\mathrm{CH}_{2} \mathrm{Cl}_{2}\right)$ followed by hexane to yield the crude $\mathrm{CH}_{2} \mathrm{Cl}_{2}$ extract (CDE) and crude hexane extract (CHE), respectively. All three crude extracts were kept in the dark at $-20^{\circ} \mathrm{C}$ until they were tested for their antiproliferation/cytotoxicity activity by the MTT assay.

\section{Chromatography}

\section{Quick column chromatography}

A sintered glass $(250 \mathrm{ml})$ column $(0.063-0.2 \mathrm{~mm}$ in size, Merck) was tightly packed with silica gel $60 \mathrm{G}$ using a vacuum pump. The crude propolis extract (CHE, CDE or CME) was mixed with silica gel 60 to a paste, left to dry and then sprinkled onto the packed column followed by a piece of filter paper $(110 \mathrm{~mm}$ in $\varnothing)$ and a cotton plug. The column was then eluted with a stepwise mobile phase of $1.5 \mathrm{~L}$ of each of $0: 1,1: 3,1: 1$, 3:1 and 1:0 (v/v) $\mathrm{CH}_{2} \mathrm{Cl}_{2}$ : hexane, followed by $3: 7(\mathrm{v} / \mathrm{v})$ $\mathrm{MeOH}$ : $\mathrm{CH}_{2} \mathrm{Cl}_{2}$, collecting $500 \mathrm{ml}$ fractions. The purity of each fraction was determined by TLC (described below), and fractions with the same TLC profile pattern were pooled prior to solvent removal by low pressure evaporation. Fractions were then screened for antiproliferation/cytotoxic activity using the MTT assay as detailed below.

\section{Adsorption chromatography}

A silica gel $60(90 \mathrm{~g})$ column $(250 \mathrm{ml})$ in hexane was prepared as described above. Fractions which showed a good antiproliferation/cytotoxic activity were dissolved in the appropriate solvent, mixed with silica gel 60 (5-7 g) and left at room temperature (RT) until dry. They were then transferred to the column and eluted as above except the stepwise elution gradient was comprised of $500 \mathrm{ml}$ of 0:1, 1:1 and 1:0 (v/v) $\mathrm{CH}_{2} \mathrm{Cl}_{2}$ : hexane and finally $\mathrm{MeOH}$, and $2.5 \mathrm{ml}$ fractions were collected. Fractions were screened for component composition by TLC profile patterns, with those with similar TLC profiles being pooled and then screened for antiproliferative/cytotoxic activity using the MTT assay.

\section{Thin layer chromatography (TLC)}

TLC plates (a silica coated plate, Merck) were cut to $5 \times$ $5 \mathrm{~cm}^{2}$ and each sample was loaded by a capillary tube onto five replicate plates. One of each of the five replicate plates was then resolved in a mobile phase of one of $0: 1,1: 1,3: 1$ and $1: 0(\mathrm{v} / \mathrm{v}) \mathrm{CH}_{2} \mathrm{Cl}_{2}$ : hexane or $1: 19(\mathrm{v} /$ v) $\mathrm{MeOH}$ : $\mathrm{CH}_{2} \mathrm{Cl}_{2}$, respectively. After the mobile phase solvent permeated to the top line of the TLC plate, the TLC plate was removed, left at RT to dry and then the resolved compounds were visualized and location marked under ultraviolet light.

\section{Antiproliferation and cytotoxicity assays against human cancer cell lines \\ Transformed (cancer) and non-transformed cell lines}

The five selected cancer cell lines used in this research were derived from human duet carcinoma (BT474, ATCC No. HTB 20), undifferentiated lung (Chaco I, National Cancer Institute), liver hepatoblastoma (Hep$\mathrm{G}_{2}$, ATCC No. HB8065), gastric carcinoma (KATO-III, ATCC No. HTB 103) and human colon adenocarcinoma (SW620, ATCC No. CCL 227) cancers. In addition, the non-transformed human foreskin fibroblast cell line (Hs27, ATCC No. CRL 1634) was used as a comparative control. All cell lines were obtained from the Institute of Biotechnology and Genetic Engineering, Chulalongkorn University. The five cancer cell lines were cultured in RPMI 1640 medium containing 5\% (v/v) fetal calf serum (FCS), while the Hs27 cell line was cultured in Basal Iscove medium containing $5 \%(\mathrm{v} / \mathrm{v}) \mathrm{FCS}$, at $37^{\circ} \mathrm{C}$ with $5 \%(\mathrm{v} / \mathrm{v}) \mathrm{CO}_{2}$ [28].

\section{Cell counts}

Cells were removed from their culture flask using standard trypsin treatment until dislodged with gentle aspiration into single cell suspensions and resuspended to ten-fold the initial volume, or as appropriate, to allow counting on an improved Neubauer counting chamber. Cells positioning at four large corner squares of the hematocytometer were counted and so the number of cells was calculated as:

Concentration of cells $($ cells $/ \mathrm{ml})=($ Number of cells $/ 4) \times$ dilution factor $\times 10^{4}$ cells $/ \mathrm{m}$

$[3-(4,5-$ dimethyl - thiazol $-2-y l) 2,5$ - diphenyl - tetrazoliumbromide $]$ (MTT) assay

The MTT assay was performed as reported by Santos et al. [29] and Hernandez et al. [17]. For each of the five cancer cell lines, $5 \times 10^{3}$ cells in $200 \mu \mathrm{l}$ of RPMI 1640 medium containing $5 \%(\mathrm{v} / \mathrm{v})$ FCS were transferred per well of a 96 well tissue culture plate, and incubated at $37^{\circ} \mathrm{C}$ in $5 \%(\mathrm{v} / \mathrm{v}) \mathrm{CO}_{2}$ for $24 \mathrm{~h}$ prior to the addition of 2 
$\mu \mathrm{l} /$ well of the test extract in dimethylsulfoxide (DMSO) at various final concentrations. The addition of $2 \mu \mathrm{l} /$ well of DMSO alone was used as the control. Cells were then incubated as above for $72 \mathrm{~h}$ before $10 \mu \mathrm{l}$ of $5 \mathrm{mg} /$ $\mathrm{ml}$ MTT was added and incubated for another $4 \mathrm{~h}$. The supernatant was then removed, the cells permeabilized and the formazan crystals dissolved by aspiration in 150 $\mu \mathrm{l}$ of DMSO and $25 \mu \mathrm{l}$ of $0.1 \mathrm{M}$ glycine prior to measuring the absorbance at $540 \mathrm{~nm}$ by a microplate reader. Three replications of each trial were performed. By assuming an equal mitochondrial metabolic activity per living cell, the absorbance is then related to the relative number of viable cells and so is reduced, relative to the control, by any antiproliferation and/or cytotoxic activity of the test compound.

Estimation of the inhibition concentration at $50 \%$ (IC 50$)$ The absorbance at $540 \mathrm{~nm}$ of the test compound treated cancer cells and the solvent only control was used to calculate the relative number of viable cells, setting that for the control as $100 \%$. The relative number of viable cells, as a \% of the control, was then calculated as follows:

$$
\text { The relative }(\%) \text { number of viable cells }=\frac{(\text { Abs of sample }) \times 100}{(\text { Abs of control })}
$$

where (Abs of sample) and (Abs of control) are defined as the absorbance at $540 \mathrm{~nm}$ of the treated cells and the control cells, respectively.

The $\mathrm{IC}_{50}$ values were graphically obtained by plotting the absorbance obtained against the corresponding different concentrations of the test compound used, and are reported as the mean \pm 1 standard error (SE). Data were statistically analyzed using the Kruskal-Wallis One Way Analysis of Variance. Significance was accepted at the $P<0.05$ level.

\section{Chemical structure analysis by spectroscopy Nuclear magnetic resonance (NMR)}

To analyze the enriched bioactive compounds, 2-3 mg of each purified active fraction was dissolved in $500 \mu \mathrm{l}$ of deuterated chloroform $\left(\mathrm{CDCl}_{3}\right)$ and transferred into an NMR tube. The sample was analyzed and recorded by a Varian Mercury ${ }^{+} 400$ NMR spectrometer operating at $400 \mathrm{MHz}$ for ${ }^{1} \mathrm{H}$ and 2D NMR (COSY, HSQC, $\mathrm{HMBC}$ ) and $100 \mathrm{MHz}$ for ${ }^{13} \mathrm{C}$ nuclei in order to search for functional groups. The chemical shift in $\delta$ (ppm) was assigned with reference to the signal from the residual protons in the deuterated solvent and TMS was used as an internal standard.

Mass spectroscopy (MS)

For each purified fraction a 1-2 mg aliquot was dissolved in ethyl acetate $(1 \mathrm{ml})$ and was then commercially analyzed at the National Science and Technology
Development Agency (NSTDA, Thailand) using ESI-MS to evaluate the molecular weight and functional group composition.

\section{DNA fragmentation}

The SW620 cancer cells or untransformed Hs27 cells (5 $\times 10^{5}$ cells/flask/ $6 \mathrm{ml}$ media) were cultured as above for $24 \mathrm{~h}$ and then exposed to the test fraction at the derived antiproliferation/cytotoxic $\mathrm{IC}_{50}$ concentration for $72 \mathrm{~h}$, observing their morphology and cell number every $24 \mathrm{~h}$. The morphology of the SW620 or Hs27 cells treated with each test compound was compared to those treated with only the DMSO solvent as the control. Cells were released by standard trypsin and aspiration, centrifugally washed at $2,000 \times \mathrm{g}$ at $15-25^{\circ} \mathrm{C}$ for $5 \mathrm{~min}$ and finally the cell pellet was resuspended in $200 \mu \mathrm{l}$ of PBS. To this 20 $\mu \mathrm{l}$ of proteinase $\mathrm{K}(>600 \mathrm{mAU} / \mathrm{ml})$ was added and total DNA was extracted using a QIAMP mini kit (Qiagen, cat. no. 51304), as per the manufacturer's instructions. The extracted DNA was stored at $-20^{\circ} \mathrm{C}$ until used, with the concentration and purity being evaluated by measuring the absorbance at 260 and $280 \mathrm{~nm}\left(\mathrm{~A}_{260 / 280}\right.$ ratio of 2.0; and an $\mathrm{A}_{260}$ of 1 being equal to $50 \mu \mathrm{g} / \mathrm{ml}$ ), and the appearance after electrophoretic resolution through a $1.8 \%(\mathrm{w} / \mathrm{v})$ agarose-TBE gel, coresolving the samples with $\lambda$ HindIII $(1.25 \mu \mathrm{g})$ and $100 \mathrm{bp}$ DNA ladder $(0.5$ $\mu \mathrm{g})$ as DNA markers. After electrophoresis, the gel was stained with $10 \mu \mathrm{g} / \mathrm{ml}$ of ethidium bromide (EtBr) for $10 \mathrm{~min}$, destained in distilled water for $20 \mathrm{~min}$ and the DNA visualized by ultraviolet transillumination.

\section{Results}

\section{Crude extract of propolis from Apis mellifera}

After sequential extraction of propolis with methanol, $\mathrm{CH}_{2} \mathrm{Cl}_{2}$ and hexane, the three crude extracts obtained (CME, $\mathrm{CDE}$ and $\mathrm{CHE}$, respectively) varied in appearance, yield and antiproliferative/cytotoxic bioactivities (Table 1). Considering the order of the sequential extraction, that the highest yield by far was found in the last solvent extraction ( $\mathrm{CHE}$ ) means that it is likely to be a realistic reflection that most of the extractable propolis components were non-polar, although of course it

Table 1 The weight and character of crude A.mellifera propolis extracts from Nan, Thailand

\begin{tabular}{ccccc}
\hline Fraction & $\begin{array}{c}\text { Weight } \\
\text { (mg) }\end{array}$ & $\begin{array}{c}\text { \% of } \\
\text { initial } \\
\text { propolis }\end{array}$ & Character & $\begin{array}{c}\text { Antiproliferative/ } \\
\text { cytotoxic }\end{array}$ \\
\hline CHE & 22,500 & $25.0 \%$ & $\begin{array}{c}\text { Dark brown, } \\
\text { sticky }\end{array}$ & Yes \\
\hline CDE & 1,320 & $1.47 \%$ & $\begin{array}{c}\text { Yellow brown, } \\
\text { sticky }\end{array}$ & Yes \\
\hline CME & 740 & $0.82 \%$ & Hazel & Weak $(>10 \mu \mathrm{g} / \mathrm{ml})$ \\
\hline
\end{tabular}


should be noted that most of the propolis was not extracted in all three solvents. Nevertheless, the brown pigments in propolis are, therefore seemingly non-polar, whilst the viscous or sticky nature may represent the wax.

\section{Antiproliferative/cytotoxic activity Effect of CHE, CDE and CME on different cancer cell lines} Five different cancer cell lines were used to screen for the in vitro antiproliferative/cytotoxic activity of the crude propolis extracts. Both the CHE and CDE revealed a strong and broadly similar antiproliferative/ cytotoxic activity on all five cell lines in a dose-dependent manner (Figure 1).

In terms of the antiproliferative/cytotoxic $\mathrm{IC}_{50}$ values, the CHE and CDE were broadly numerically similar across all five cell lines and between both extracts, ranging from $41.3 \mu \mathrm{g} / \mathrm{ml}$ (CHE on Chaco) to $53.5 \mu \mathrm{g} / \mathrm{ml}$ (CDE on Hep-G2) (Table 2). In contrast, the CME was inactive at these concentrations showing a much weaker antiproliferative/cytotoxic activity (Figure 1) with over ten-fold higher $\mathrm{IC}_{50}$ values, ranging from 500 to $605 \mu \mathrm{g} /$ $\mathrm{ml}$ (Table 2).

\section{Antiproliferative/cytotoxic effect of CHE fractions I - V on the different cancer cell lines}

Although the CHE and CDE presented very similar antiproliferative/cytotoxic activities against the five selected cell lines, the yield of CHE was significantly (17-fold) greater and thus was selected for further fractionation by quick column chromatography. This yielded five fractions of distinct compositions, as determined by the TLC profile patterns, labeled as CHE fractions I - V, with by far the highest yield being found in Fraction $\mathrm{V}$ $(4,300 \mathrm{mg})$, followed by fractions III and IV with a 13.4and 15.9- fold lower yield, respectively, whilst fractions I and II were just minor components (Table 3 ).

A strong in vitro antiproliferative/cytotoxic activity against all five selected human cancer cell lines was noted with fraction $\mathrm{V}$, and against two and three of the cell lines for fractions IV and II, respectively (Table 4 and Figure 2), but no significant activity was noted for fractions I and II.

Of the three positive fractions, fraction $\mathrm{V}$ had the highest antiproliferative/cytotoxic activity against each of the five selected cancer cell lines, with $\mathrm{IC}_{50}$ values ranging from $7.37 \pm 0.23 \mu \mathrm{g} / \mathrm{ml}$ (SW260) to $29.36 \pm$ $1.36 \mu \mathrm{g} / \mathrm{ml}$ (BT474). Fraction III showed broadly similar antiproliferative/cytotoxic activities, with $\mathrm{IC}_{50}$ values ranging from $13.69 \pm 1.44 \mu \mathrm{g} / \mathrm{ml}$ (KATO-III) to $19.94 \pm 1.83 \mu \mathrm{g} / \mathrm{ml}$ (SW620). Finally, fraction IV had the lowest antiproliferative/cytotoxic activity of the three positive fractions, and only on two of the five tested cell lines with $\mathrm{IC}_{50}$ values of $40.16 \pm 2.66 \mu \mathrm{g} / \mathrm{ml}$ and $44.56 \pm 1.89 \mu \mathrm{g} / \mathrm{ml}$.

\section{In vitro antiproliferative/cytotoxic effect of compounds 1 and 2 on the five different cancer cell lines}

Since CHE fractions V and III showed the highest antiproliferative/cytotoxic activities on the five screened human cancer cell lines, they were further purified by adsorption chromatography, yielding 88 and 92 fractions, respectively. However, in the TLC pattern profiles of all these fractions two dominant spots were clearly observed, one from CHE fraction III (compound 1) and the other from CHE fraction V (compound 2). After recovery from the TLC plates, compounds 1 and 2 were found to both have a strong antiproliferative/cytotoxic activity against the five different cancer cell lines in this MTT assay (Figure 3). The derived $\mathrm{IC}_{50}$ values of compound 1 for the SW620, KATO-III and BT474 cancer cell lines were 1.53- to 1.98- fold lower than that for the non-transformed $\mathrm{Hs} 27$ cell line, but in contrast, the $\mathrm{IC}_{50}$ values for the Hep- $\mathrm{G}_{2}$ and $\mathrm{Chaco}$ cancer cell lines were essentially the same as the Hs27 cell line (Table 5). Thus, the antiproliferation/cytotoxic activity of compound 1 on Hs27 is of concern.

Compound 2 had a higher antiproliferative/cytotoxic activity than compound 1 for all five different cancer cell lines (Figure 3), with $\mathrm{IC}_{50}$ values ranging from < 3.13 to $6.0 \mu \mathrm{g} / \mathrm{ml}(\sim 6.82$ to $13.1 \mu \mathrm{M})$ for the five different cell lines, but it was equally effective against the non-cancer Hs27 cell line (Table 5), which is again of some concern for any potential in vivo application.

\section{Structure analysis of compounds 1 and 2}

Compounds 1 and 2 were analyzed by $\left[{ }^{1} \mathrm{H}\right]$-NMR and ESI-MS spectroscopy. Compound 1 showed the characteristic signals of an m-disubstituted benzene $\left[\delta_{\mathrm{H}} 7.05\right.$ $(1 \mathrm{H}, \mathrm{H}-5), 6.67(1 \mathrm{H}, \mathrm{H}-6), 6.58(1 \mathrm{H}, \mathrm{H}-2), 6.57(1 \mathrm{H}, \mathrm{H}-$ 4)] and the characteristic resonances of the hydroxyl group from the chemical shift of carbon at $\delta_{\mathrm{C}} 155.4$ ppm. In addition, resonances at $\delta_{\mathrm{H}} 5.28(2 \mathrm{H}, \mathrm{m})$ suggested the presence of an olefinic proton. The Z-geometry of two olefinic protons, which were located at alkyl side chain, was assigned from the chemical shift of allylic carbons $\left(\delta_{\mathrm{C}} 27.2\right.$ and 26.9). The presence of an alkyl group (R-) was indicated by the signal of methylenes $\left(-\mathrm{CH}_{2}-\right)$ in the range of $1.2-2.5 \mathrm{ppm}$ in addition to the terminal methyl group $[0.82(3 \mathrm{H}, \mathrm{t}, J=6.8 \mathrm{~Hz})]$. The chain length could not be determined exactly due to the lack of a calculated molecular mass, leaving an incompletely deduced structural formula, but it was categorized as a member of the cardanol group (Figure $4 \mathrm{~A})$.

The molecular formula of compound 2 was revealed to be $\mathrm{C}_{31} \mathrm{H}_{54} \mathrm{O}_{2}$ by ESI-MS $\left[\mathrm{m} / z(\mathrm{M}+\mathrm{H})^{+}\right]$, along with the characteristic signals of a $\mathrm{m}$-trisubstituted benzene [ $\delta_{\mathrm{H}} 6.17(2 \mathrm{H}, \mathrm{H}-4$, and $\left.\mathrm{H}-6), 6.10(1 \mathrm{H}, \mathrm{H}-2)\right]$, and the characteristic resonances of the hydroxyl group from the 

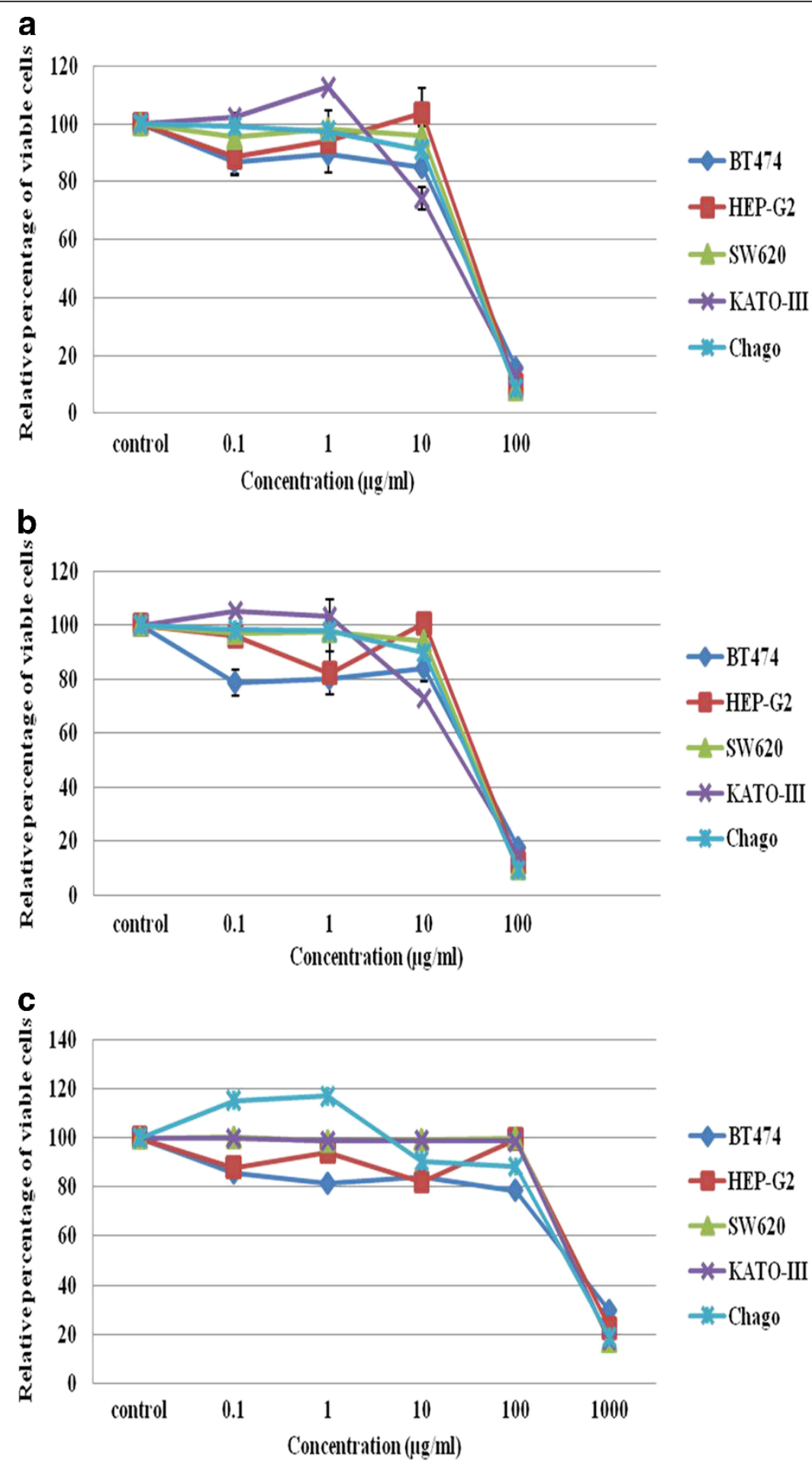

Figure 1 In vitro antiproliferative-cytotoxic activity of the (A) CHE, (B) CDE and (C) CME crude propolis extracts on five different human cancer cell lines after exposure to the test extracts for $\mathbf{7 2} \mathbf{~ h}$. The data, as the percentage of viable cells relative to that of the control, are expressed as the mean $\pm 1 \mathrm{SE}$.

single chemical shift of carbon at $\delta_{\mathrm{C}} 156.5 \mathrm{ppm}$ due to the symmetry. In addition, the resonances at $\delta_{\mathrm{H}} 5.28$ $(2 \mathrm{H}, \mathrm{m})$ suggested the presence of olefinic protons. The
Z-geometry of two olefinic protons, which were located at the alkyl side chain, was assigned from the chemical shift of allylic carbons $\left(\delta_{C} 27.2\right.$ and 26.9). The presence 
Table 2 The in vitro antiproliferative/cytotoxic $I_{50}$ values of the CHE, CDE and CME on selected cancer cell lines

\begin{tabular}{cccc}
\hline \multirow{2}{*}{$\begin{array}{c}\text { Cancer } \\
\text { cell lines }\end{array}$} & \multicolumn{3}{c}{$\mathrm{IC}_{\mathbf{5 0}}(\boldsymbol{\mu g} / \mathrm{ml})$} \\
\cline { 2 - 4 } & CHE & $\mathrm{CDE}$ & $\mathrm{CME}$ \\
\hline BT474 & $48.3 \pm 1.6^{\mathrm{a}}$ & $52.6 \pm 3.7^{\mathrm{a}}$ & $500 \pm 50^{\mathrm{b}}$ \\
\hline Chaco & $41.3 \pm 3.75^{\mathrm{a}}$ & $44.7 \pm 0.33^{\mathrm{a}}$ & $580 \pm 20^{\mathrm{b}}$ \\
\hline KATO-III & $42.5 \pm 6.61^{\mathrm{a}}$ & $43.8 \pm 6.5^{\mathrm{a}}$ & $600 \pm 50^{\mathrm{b}}$ \\
\hline SW620 & $45.3 \pm 0.33^{\mathrm{a}}$ & $46.0 \pm 0.57^{\mathrm{a}}$ & $555 \pm 7.5^{\mathrm{b}}$ \\
\hline Hep-G2 & $52.4 \pm 3.7^{\mathrm{a}}$ & $53.5 \pm 0.5^{\mathrm{a}}$ & $605 \pm 39.1^{\mathrm{b}}$ \\
\hline
\end{tabular}

Data are shown as the mean $\pm 1 \mathrm{SE}$ and are derived from three independent repeats after a $72 \mathrm{~h}$ exposure to the test extracts. Means (within and between columns) with a different lowercase superscript letter are significantly different $(p<0.05$; Kruskal-Wallis test)

of the alkyl group (R-) was indicated by the signal of methylenes $\left(-\mathrm{CH}_{2}-\right)$ in the range of $1.1-2.6 \mathrm{ppm}$ in addition to thermal methyl $[0.82(3 \mathrm{H}, \mathrm{t}, J=6.8 \mathrm{~Hz})]$. From the NMR and ESI-MS results compound 2 was ascribed to be a member of the cardol group, although its exact formula is unresolved (Figure 4B).

\section{Morphology of the SW620 and Hs27 cells after in vitro exposure to compound 1 (cardanol) or compound 2 (cardol) SW620 cancer cell line}

SW620 cells were cultured for up to $96 \mathrm{~h}$ in complete medium supplemented with DMSO alone (control) or the same amount of DMSO with either compound 1 (cardanol) or compound 2 (cardol) at their derived $\mathrm{IC}_{50}$ values for evaluation of their antiproliferation/cytotoxic activity, namely at 10.76 and $3.0 \mu \mathrm{g} / \mathrm{ml}$, respectively. This is equivalent to $6.54 \mu \mathrm{M}$ for compound 2 , but the molarity of compound 1 is unknown since its molecular mass was not obtained. The cell morphology and cell number were observed at 0, 24, 48, 72 and $96 \mathrm{~h}$. As set up $(0 \mathrm{~h})$, the cells looked flat and spindle shaped (Figure $5 \mathrm{~A})$. No significant change in the cell morphology was observed in all samples, that is the solvent only control and the cardanol and cardol treated cells, after $24 \mathrm{~h}$ of treatment time with cells still appearing flat and in a spindle shape (data not shown). However, after $48 \mathrm{~h}$ of in vitro culture vacuolation could be seen inside the
Table 4 The $I C_{50}$ values for the in vitro antiproliferation/ cytotoxic activity of CHE fractions I - IV on five human cancer cell lines

\begin{tabular}{|c|c|c|c|c|c|}
\hline \multirow{2}{*}{$\begin{array}{c}\text { Cancer } \\
\text { cell } \\
\text { lines }\end{array}$} & \multicolumn{5}{|c|}{$I C_{50}$ values $(\mu \mathrm{g} / \mathrm{ml})$} \\
\hline & $\begin{array}{c}\text { Fraction } \\
\text { I }\end{array}$ & $\begin{array}{c}\text { Fraction } \\
\text { II }\end{array}$ & Fraction III & $\begin{array}{c}\text { Fraction } \\
\text { IV }\end{array}$ & Fraction V \\
\hline BT474 & ND & ND & ND & ND & $\begin{array}{c}29.36 \pm \\
1.36\end{array}$ \\
\hline Chaco & ND & ND & ND & ND & $\begin{array}{c}12.75 \pm \\
0.68\end{array}$ \\
\hline KATO-III & ND & ND & $\begin{array}{c}13.69 \pm \\
1.44^{\mathrm{a}}\end{array}$ & $\begin{array}{c}40.16 \pm \\
2.66^{b}\end{array}$ & $\begin{array}{c}15.21 \pm \\
2.13^{\mathrm{a}}\end{array}$ \\
\hline SW620 & ND & ND & $\begin{array}{c}19.94 \pm \\
1.83^{\mathrm{b}}\end{array}$ & $\begin{array}{c}44.56 \pm \\
1.89^{c}\end{array}$ & $\begin{array}{c}7.37 \pm \\
0.23^{\mathrm{a}}\end{array}$ \\
\hline $\mathrm{Hep}-\mathrm{G}_{2}$ & ND & ND & $\begin{array}{c}19.37 \pm \\
0.36\end{array}$ & ND & $\begin{array}{c}22.22 \pm \\
0.69\end{array}$ \\
\hline
\end{tabular}

ND indicates no $\mathrm{IC}_{50}$ values were obtained since no significant antiproliferative/cytotoxic activity was found in this tested concentration range. Data is shown as the mean \pm 1 SE from three independent repeats after a $72 \mathrm{~h}$ exposure to the test compound. Means (within and between columns) with a different lowercase superscript letter are significantly different ( $p \leq 0.05$; Kruskal-Wallis test)

cells treated with compound 1 or 2 , but not in the control cells which were still normal (Figure 5).

By $72 \mathrm{~h}$ of cell culture, the control cells still appeared normal (but more dense and approaching or reaching confluency), whilst apparent DNA condensation within the nucleus was visible in both the cardanol and cardol treated cells (Figure 6). In addition, morphological changes and cell debris (indicated by a red arrow) were visible, as well as a reduced cell density compared to the control.

Finally, after $96 \mathrm{~h}$ of cell culture, whilst no change in the morphology of the control cells was noted, significantly higher levels of cells with DNA condensation within their nucleus (red arrow) along with cell debris, a loss of cell adhesion and a significantly reduced cell number were clearly visible in the cardanol and cardol treated cells (Figure 6).

\section{Hs27 cells}

In contrast to that observed for the SW620 cancer cell line, no morphological changes were observed in the non-transformed Hs27 cell line after similar in vitro

Table 3 The yield and character of the five CHE fractions obtained after quick column chromatography

\begin{tabular}{|c|c|c|c|c|c|}
\hline Fraction & Weight (mg) & $\begin{array}{c}\text { Yield (\% of } \\
\text { CHE/total propolis) }\end{array}$ & Character & $\begin{array}{l}\text { Antiproliferative/ } \\
\text { cytotoxic activity }^{\text {a }}\end{array}$ & TLC plates $^{b}$ \\
\hline I & 80 & $0.36 \% / 0.09 \%$ & Clear wax & - & 3 \\
\hline$\|$ & 20 & $0.09 \% / 0.02 \%$ & Clear yellow oil & - & 3 \\
\hline III & 320 & $1.42 \% / 0.36 \%$ & Yellow oil & 3 cell lines & 1 \\
\hline IV & 270 & $1.2 \% / 0.30 \%$ & Yellow powder & 2 cell lines & 3 \\
\hline V & 4,300 & $19.1 \% / 4.78 \%$ & Dark brown oil & all 5 cell lines & 2 \\
\hline
\end{tabular}

${ }^{a}$ Number of the five human cancer cell lines in which a significant antiproliferative/cytotoxic activity was induced by the extract after a $72 \mathrm{~h}$ exposure, as determined by the MTT assay

${ }^{\mathrm{b}}$ The minimum number of distinct compounds in the fraction as determined by evaluation of the different TLC plates 

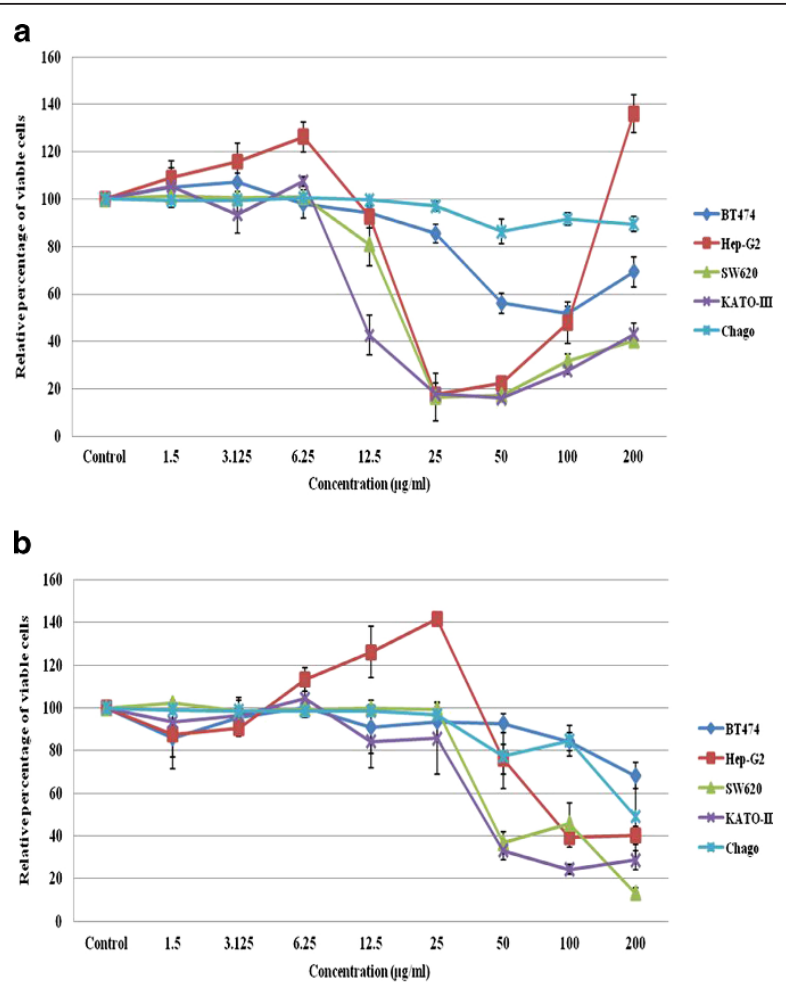

c

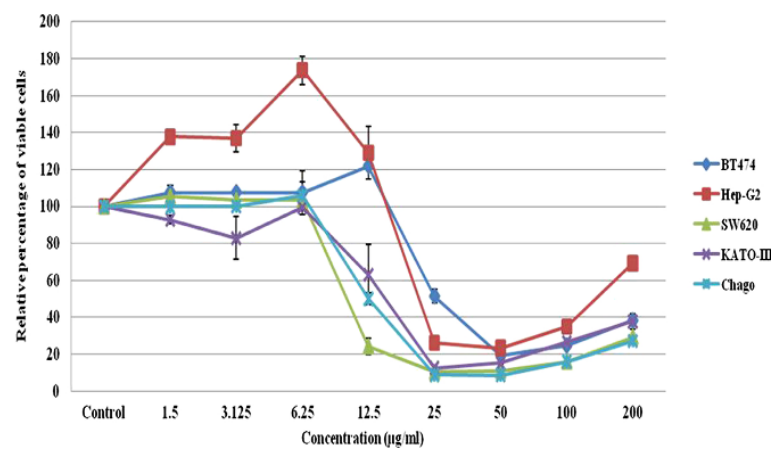

Figure 2 In vitro antiproliferative/cytotoxic activity of CHE fractions (A) III, (B) IV and (C) V on the five different cancer cell lines. The antiproliferative/cytotoxic effect is expressed in terms of the percentage of viable cells relative to the control after $72 \mathrm{~h}$ exposure to the test fractions, and is shown as the mean $\pm 1 \mathrm{SE}$.

treatment with the same doses of cardanol or cardol (Figure 7). That is the cells looked flat and were attached to the substratum at all time points in all three treatments.

\section{DNA Fragmentation}

In order to find out whether compounds 1 and 2 (cardanol and cardol) could induce apoptosis or necrosis through damage to the DNA of the cells in culture or not, the DNA was extracted from cultured SW620 cells and examined for size following resolution by agaroseTBE gel electrophoresis. If they play no role in DNA damage, then the DNA would be expected to be intact and appear as a high molecular weight and sharp band following agarose - TBE electrophoresis, whereas, in contrast, if significant damage to the DNA was induced then a smear of fragmented DNA or a 180-200 bp interval ladder (apoptosis) will be seen. Neither compound 1 (cardanol) nor compound 2 (cardol) treated SW620 cells or the Hs27 cells revealed any evidence of fragmentation of the DNA, neither as an apoptotic ladder nor a general degradation smear (Figure 8).

From the analysis of the extracted DNA, which was a large single band and not a 180-200 bp ladder or smear, it is possible that compounds 1 and 2 did not kill the cells by apoptosis since no DNA ladder pattern was 

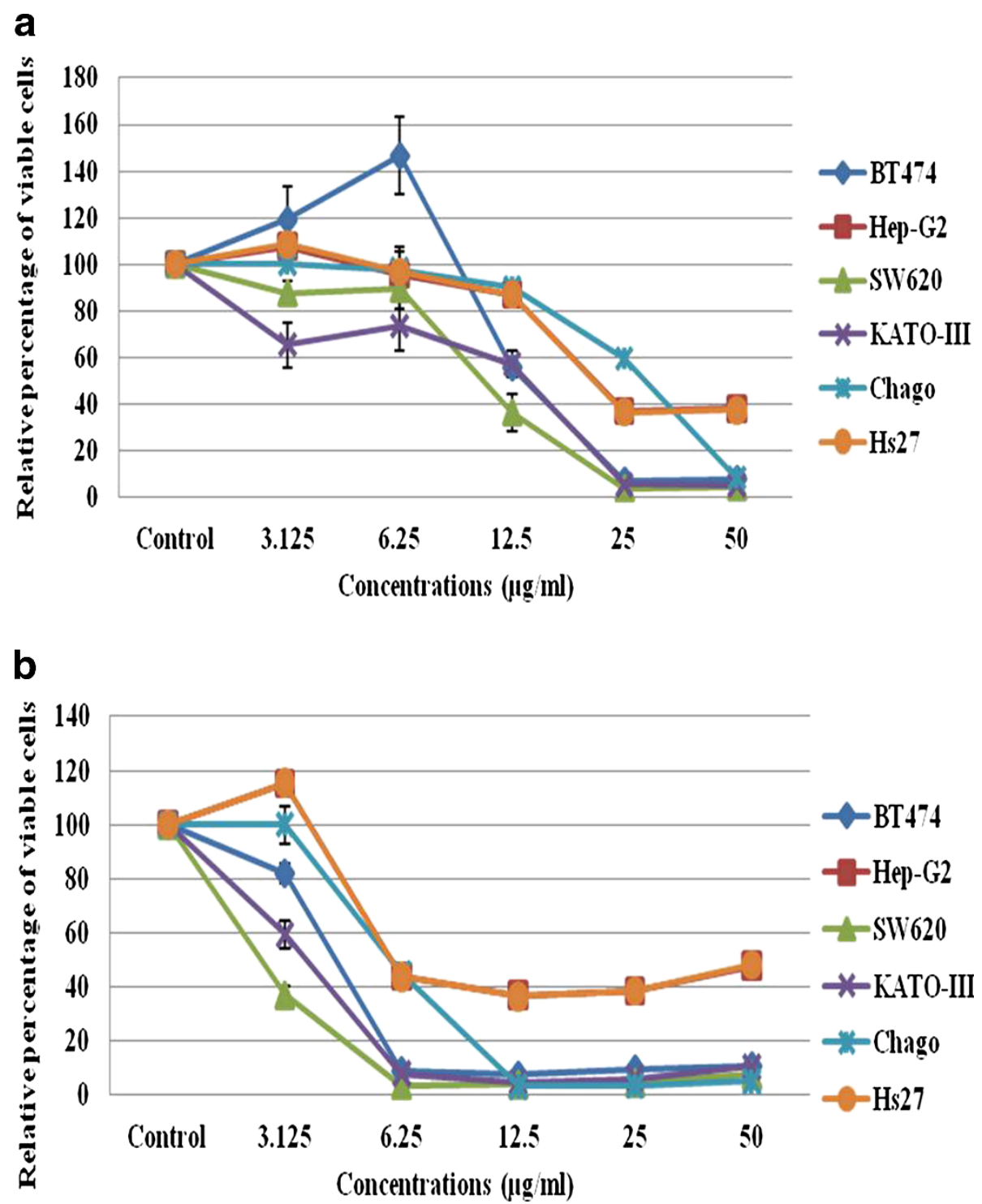

Figure 3 In vitro cytotoxic/antiproliferative activity of (A) compound 1 and (B) compound 2 on the five different cancer cell lines plus the non-transformed Hs27 cell line. The antiproliferative/cytotoxic effect is expressed in terms of the percentage of viable cells relative to the control after $72 \mathrm{~h}$ exposure to the test compound, and is shown as the mean $\pm 1 \mathrm{SE}$.

seen. In addition, no smear was found suggesting no significant level of DNA damage. This does not contrast with the notion of death by necrosis, as suggested by the morphology changes, since the badly damaged (necrotic) cells would have been removed in the washing process during cell harvesting and before DNA extraction.

\section{Discussion}

In this research, propolis from A. mellifera was used to determine the in vitro antiproliferative/cytotoxic activity on five human cancer cell lines. Although there are many bee species that can produce propolis, especially stingless bees, such as Melipona fasciculate: [30] and Tetragonula carbonaria [31], A. mellifera was chosen since it is commonly cultured for honey, is an easy to manage species in apiaries and so makes access to propolis on a commercial, as well as environmentally sustainable, scale feasible. In addition, the bioactivities of propolis are reported to depend on the geographical regions [32], seasons [14] and other external factors. Thus, the propolis of $A$. mellifera from Thailand, a floral biodiversity hotspot, is of interest since it has never been reported previously yet maybe different from the propolis of this species reported previously from other regions. The selection of Nan province was based upon 
Table 5 The in vitro antiproliferation/cytotoxic activity $\mathrm{IC}_{50}$ values of compounds 1 and 2

\begin{tabular}{|c|c|c|c|}
\hline \multirow{2}{*}{$\begin{array}{l}\text { Cancer } \\
\text { cell } \\
\text { lines }\end{array}$} & \multicolumn{3}{|c|}{$\mathrm{IC}_{50}$ value $^{1}$} \\
\hline & $\begin{array}{c}\text { Compound } 1(\mu \mathrm{g} / \\
\mathrm{ml})^{2}\end{array}$ & & $\begin{array}{c}\text { Compound } 2(\mu \mathrm{g} / \mathrm{ml} / \\
\mu \mathrm{M})\end{array}$ \\
\hline BT474 & $13.95 \pm 0.9$ & $\begin{array}{c}4.41 \pm \\
0.15 \\
\end{array}$ & $9.61 \pm 0.33$ \\
\hline Chaco & $29.30 \pm 1.08$ & $\begin{array}{c}5.78 \pm \\
0.07 \\
\end{array}$ & $12.60 \pm 0.15$ \\
\hline KATO-III & $13.71 \pm 1.42$ & $\begin{array}{c}4.03 \pm \\
0.13 \\
\end{array}$ & $8.78 \pm 0.28$ \\
\hline SW620 & $10.76 \pm 0.92$ & $<3.125$ & $<6.81$ \\
\hline Hep- $G_{2}$ & $21.53 \pm 0.35$ & $\begin{array}{l}5.97 \pm \\
0.15\end{array}$ & $1.30 \pm 0.33$ \\
\hline $\mathrm{Hs} 27$ & $21.35 \pm 0.52$ & $\begin{array}{l}5.97 \pm \\
0.15\end{array}$ & $1.30 \pm 0.33$ \\
\hline
\end{tabular}

${ }^{1}$ Data are shown as the mean $\pm 1 \mathrm{SE}$ after a $72 \mathrm{~h}$ exposure to the test compounds, and are derived from three independent experiments

${ }^{2}$ The molar concentration of compound 1 could not be given as its molecular formulae, and thus molar mass, is not known the diverse flora still present in this region of Thailand, and so the potential for novel compounds in the propolis. This native and remote area of the country is dry, mountainous and full of deep forests with unique plants, such as Bretschneidera sinensis Hemsl.

Propolis was initially sequentially extracted with $\mathrm{MeOH}$ (high-polar solvent), then $\mathrm{CH}_{2} \mathrm{Cl}_{2}$ (mediumpolar solvent) and finally hexane (non-polar solvent). Both the hexane (CHE) and $\mathrm{CH}_{2} \mathrm{Cl}_{2}$ (CDE) extracts revealed a good antiproliferative/cytotoxic activity against the five selected human cancer cell lines, as determined by the MTT assay. Thus, in general the antiproliferative/cytotoxic compounds in this propolis from A. mellifera in Nan, Thailand, are unlikely to be highly polar. This notion is supported by Castro et al. [33] who reported the best antiproliferative activity against HeLa tumor cells was from prenylated benzophenone (hyperibone A), which is found in the CHE of Brazilian propolis, with an $\mathrm{IC}_{50}$ value of $175.6 \mathrm{nM}$ (91 $\mathrm{ng} / \mathrm{ml})$.
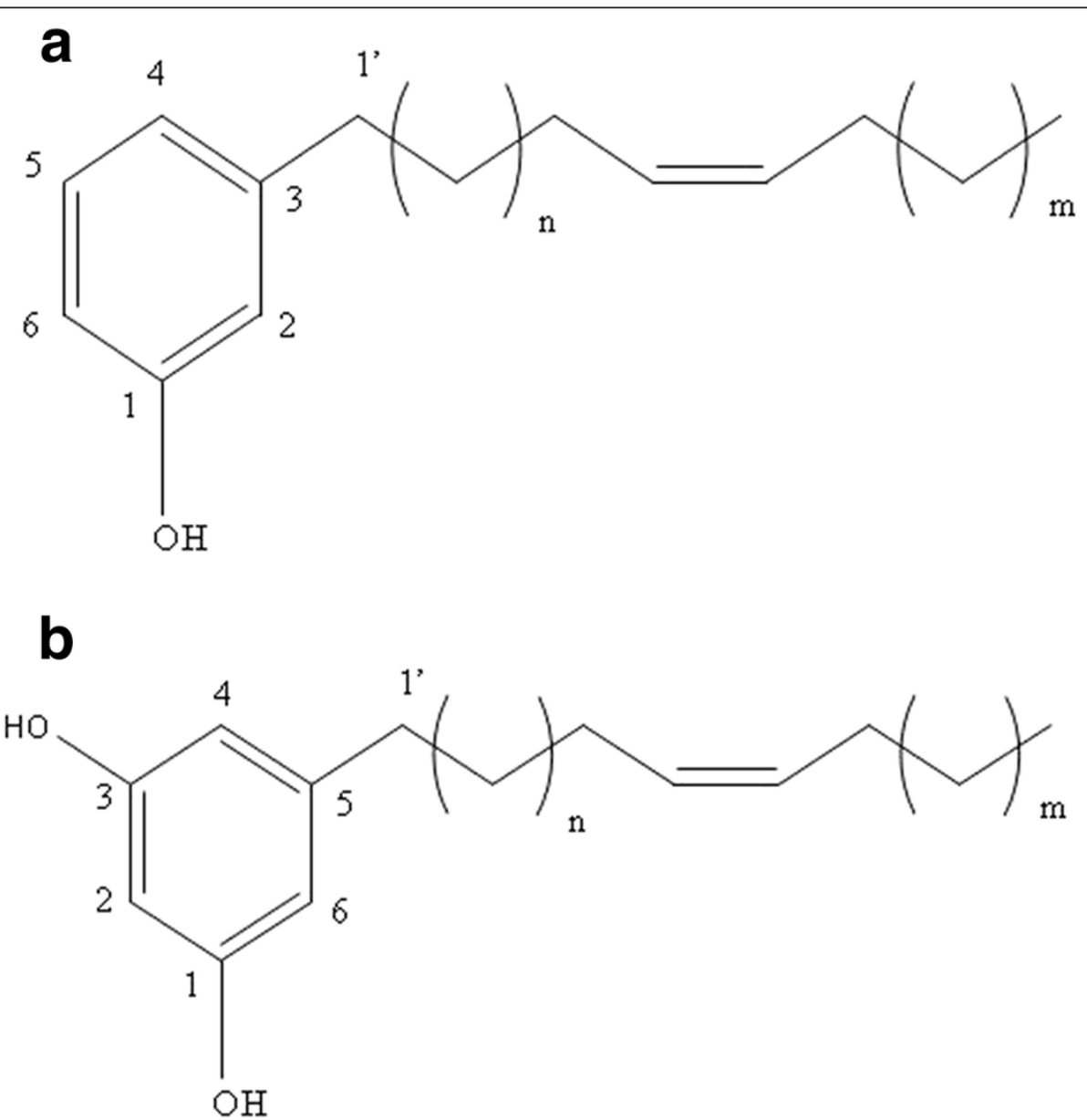

Figure 4 The proposed formula structure of (A) compound 1, a cardanol and (B) compound 2, a cardol. 

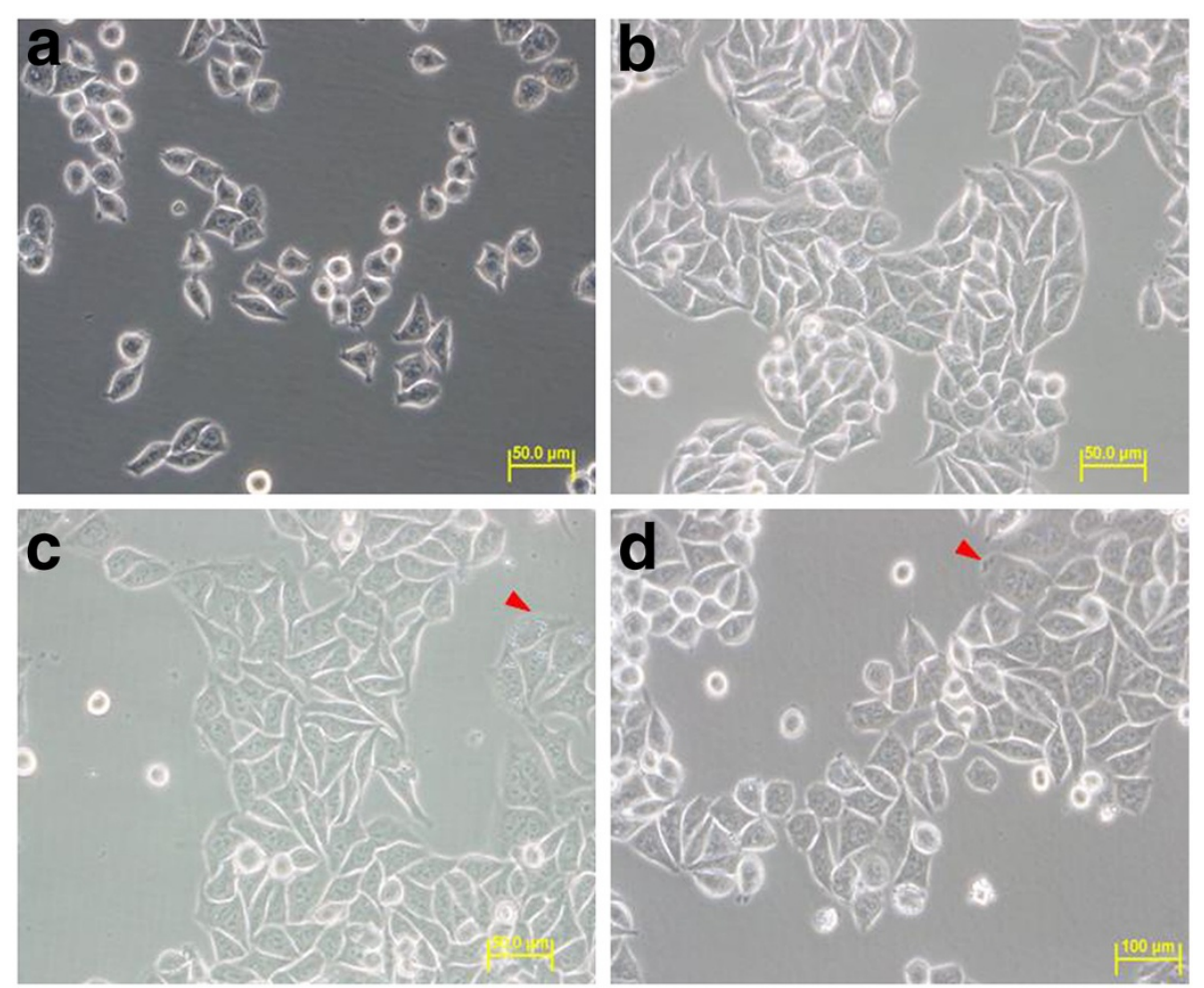

Figure 5 SW620 cells after (A) $0 \mathrm{~h}$ culture and (B-D) after $48 \mathrm{~h}$ of culture with (B) the DMSO solvent alone (control) or with (C) compound 1 (cardanol) at its $I_{50}$ value $(10.76 \mu \mathrm{g} / \mathrm{ml})$, or (D) compound 2 (cardol) at its $I_{50}$ value $(3.0 \mu \mathrm{g} / \mathrm{ml} ; 6.54 \mu \mathrm{M})$. All images are magnified at 40x. Images shown are representative of at least five such fields of view per sample and three independent trials.

Both $\mathrm{MeOH}$ and water/EtOH, two polar solvents, could be used to extract the antioxidant activity from propolis from Portugal [34], whilst other optimal extraction solvents were reported to be chloroform for the antimicrobial activity against oral pathogens [30] and ethanol for the anti-influenza A virus activity [35]. Thus, the bioactivities of crude propolis extracts, and so the frequently, albeit incorrectly, inferred propolis bioactivities, depend also on the extraction solvents used as well.

The different cell line sensitivities and $\mathrm{IC}_{50}$ values for the antiproliferative/cytotoxic activity before and after fractionation by adsorption chromatography could represent the removal of inhibitory components that exert an antagonistic effect, or the separation of different components with different activities. Comparing the $\mathrm{IC}_{50}$ values of compounds 1 and 2 (Table 5 and Figure 3 ), compound 2 (cardol) looked to be a promising agent for anti-cancer treatment in terms of its lower $\mathrm{IC}_{50}$ values for antiproliferation/cytotoxicity compared to compound 1 (cardanol), assuming that (i) the same $\mathrm{IC}_{50}$ values observed against the non-transformed $\mathrm{Hs} 27$ cell line reflects an antiproliferative activity only and not a cytotoxic activity and that (ii) a specific delivery system could be used to target the cancer cells or tumor area rather than systemic delivery, so as to avoid or minimize side affects. Moreover, consumption of the crude form of propolis should be warned against because Aliboni et al. [26] reported that propolis can cause an allergic reaction to sensitive individuals due to the presence of the two allergenic esters, benzyl salicylate and benzyl cinnamate.

Both compounds 1 and 2 (cardanol and cardol) are phenolic lipids with an amphiphilic character [36] derived from the hydrophilic hydroxyl group and the hydrophobic long chain hydrocarbon [37]. These compounds are found in tropical plants in the family Anacardiaceae, both in native and cultivated cultures [38]. Economic plants in this family include cashew nut, mango and ginkgo [39], whilst the diversity of both compounds is high, such as in the form of anacardic acid, catechol, resorcinol and gingkolic acid [37]. Indeed, members of these groups have previously been reported to exhibit diverse bioactivities, such as antibacterial [40], antiplasmodial [41], antioxidant [42] and antifungal activities [43]. However, the diversity of chemical structures in the cardanol and cardol groups may account for the diverse bioactivities [44], rather than a few pluripotent compounds.

Wang et al. [45] reported that they could purify CAPE from propolis, and that it showed an antiproliferative 

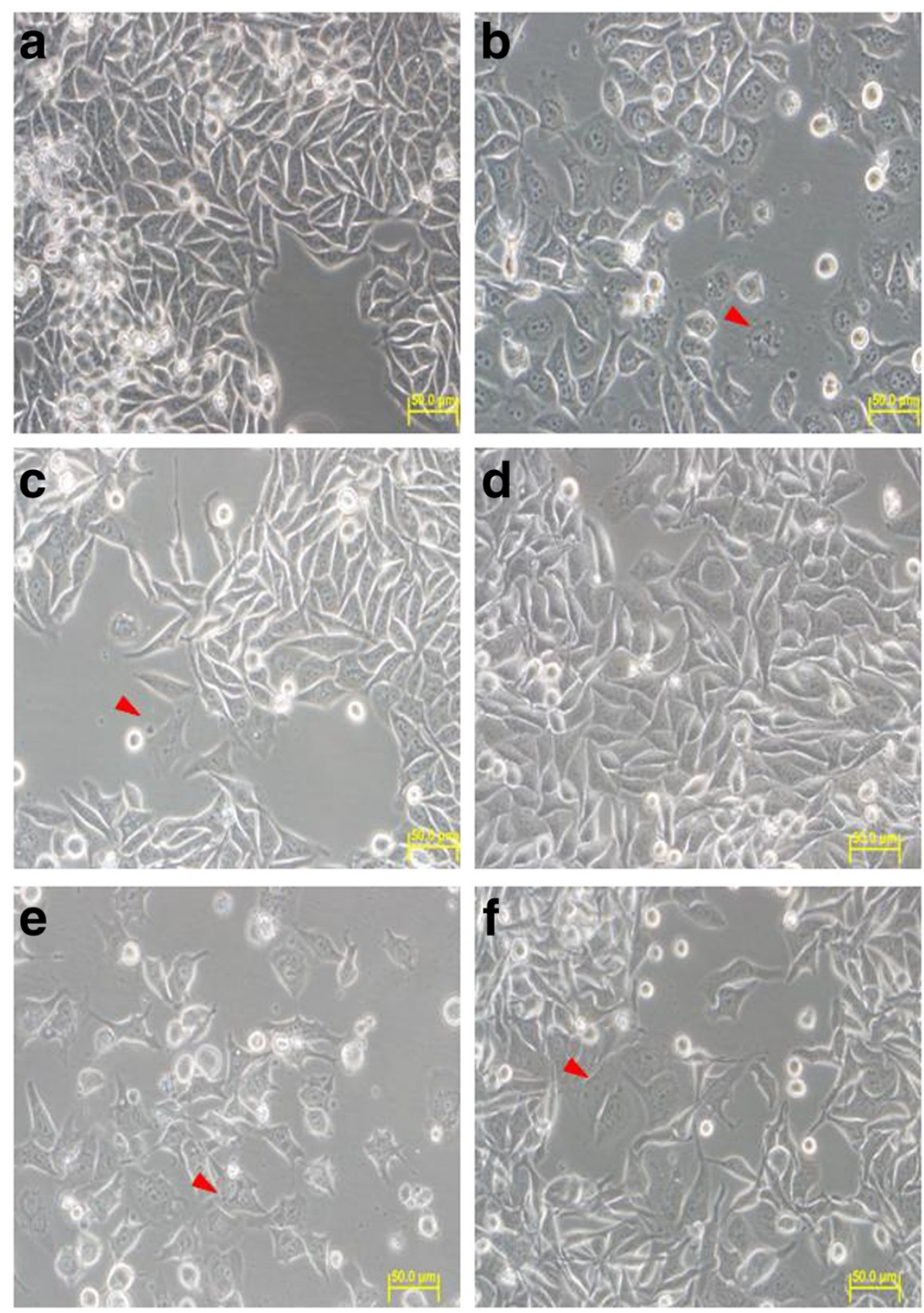

Figure 6 SW620 cells after (A-C) $72 \mathrm{~h}$ or (D-F) $96 \mathrm{~h}$ of culture in (A, D) the DMSO solvent alone (control) or (B, E) with compound 1 (cardanol) at its $\mathrm{IC}_{50}$ value $(10.76 \mu \mathrm{g} / \mathrm{ml})$, or $(C, F)$ compound 2 (cardol) at its $I C_{50}$ value $(3.0 \mu \mathrm{g} / \mathrm{ml} ; 6.54 \mu \mathrm{M})$. All images are magnified at $40 \times$. Images shown are representative of at least five such fields of view per sample and three independent trials.

activity on the human colorectal cancer cell line $(\mathrm{CRC})$ in a dose- and time-dependent manner. The $\mathrm{IC}_{50}$ value of CAPE after $72 \mathrm{~h}$ treatment was $22.7 \mu \mathrm{M}(6.47 \mu \mathrm{g} / \mathrm{ml})$. Comparing compound 2 (cardol) from our research with that for CAPE, the antiproliferative/cytotoxic activity $\mathrm{IC}_{50}$ value of compound 2 on the SW620 cell line (< $3.13 \mu \mathrm{g} / \mathrm{ml} ;<6.8 \mu \mathrm{M})$, which is also a human colorectal cancer cell line, was over 3.3 -fold lower than the $\mathrm{IC}_{50}$ value of CAPE on CRC (in terms of molarity). Thus, subject to the risk of side effects, compound 2 (cardol) purified from Thai $A$. mellifera propolis could be a better antiproliferative agent against human colorectal cancer cells.

CAPE is also reported to have an effect on breast cancer cells, with a similar $\mathrm{IC}_{50}$ value on the $\mathrm{ER}^{-}$and $\mathrm{ER}^{+}$ MDA-231 and MCF-7 cell lines, respectively, of $15 \mu \mathrm{M}$ 

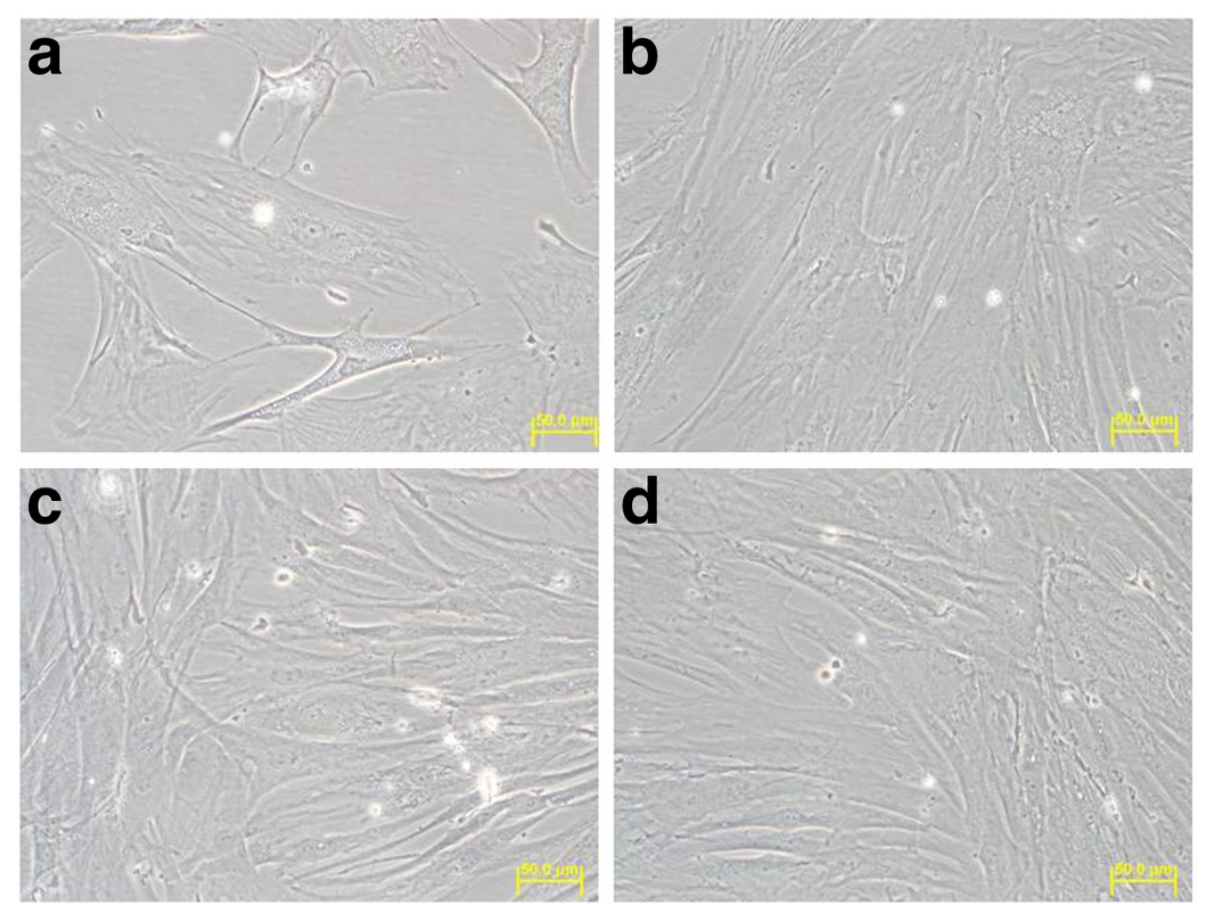

Figure 7 The shape of Hs27 cells at (A) $0 \mathrm{~h}$ and (B-D) $96 \mathrm{~h}$ of in vitro culture with (A, B) DMSO solvent only (control), (C) compound 1 (cardanol) at its $\mathrm{IC}_{50}$ value $\left(10.76 \mu \mathrm{g} / \mathrm{ml}\right.$ )and (D) compound 2 (cardol) at its $\mathrm{IC}_{50}$ value $(3.0 \mu \mathrm{g} / \mathrm{ml} ; 6.54 \mu \mathrm{M})$. All images were magnified at 40x. Images shown are representative of at least five such fields of view per sample and three independent trials.

$(4.26 \mu \mathrm{g} / \mathrm{ml})$ [22]. Thus, the $\mathrm{IC}_{50}$ value reported for CAPE is broadly similar in terms of mass, but some 1.5fold higher in terms of molarity, to that seen here for compound 2 (cardol) against the breast cancer cell line BT474 $(4.41 \mu \mathrm{g} / \mathrm{ml} ; 9.61 \mu \mathrm{M})$, again indicating that cardol purified from Thai $A$. mellifera propolis could be an interesting antiproliferative agent against human breast cancer cells.

CAPE has been reported to display a broad target range inhibiting the growth of many cancer cell lines, such as C6 glioma cells [46] and human leukemia (HL60) cells [47], and also to be cytotoxic to the neck metastasis of gingiva carcinoma (GNM) and tongue squamous cell carcinoma (TSCCa) cells [48]. Moreover, CAPE showed a strong inhibitory effect on the matrix metalloproteinase (MMP-9), which is related to the invasion and metastasis ability of hepatocellular carcinomas [49]. In the future, the effect of compounds 1 (cardanol) and 2 (cardol) from this Thai A. mellifera propolis should be evaluated accordingly.

Since many cancer drugs or chemotherapy agents used nowadays cause adverse side effects through being cytotoxic to normal cells, it is necessary to find new compounds that will not cause such adverse side effects and not be cytotoxic to normal cells. Therefore, the apparent absence of cytotoxicity of compounds 1 (cardanol) and 2 (cardol) to the non-transformed Hs27 cell line in vitro is of interest, but requires conformation in a broader range of non-transformed cell lines. However, against that was the observed antiproliferative affect noted on the Hs27 cell line, which may well then result in strong adverse side affects and so the requirement for more localized drug delivery systems. This is because although compounds 1 (cardanol) and 2 (cardol) affected some cancer cell lines in vitro with lower $\mathrm{IC}_{50}$ values than that against the non-transformed Hs27 cell line, this small difference is unlikely to be sufficient to allow safe systemic administration without side affects, but may be sufficient when targeted local delivery is performed $[50,51]$.

Propolis and its phenolic compounds have been reported to induce the death of cancer cells either by necrosis [52] or by apoptosis, the latter of which might be by mitochondria mediated- [21] or death signal mediated- [53] apoptosis. Thus, the in vitro effects of compounds 1 and 2 upon the cell morphology and DNA fragmentation of the cell lines was observed.

A change in the cell morphology with a decrease in the cell number was observed for SW620 cells when cultured in vitro with compounds 1 (cardanol) or 2 (cardol), which is consistent with a cytotoxic effect. In contrast, no change in the cell morphology was observed with the Hs27 cells under the same conditions. It is likely that compounds 1 (cardanol) and 2 (cardol) 


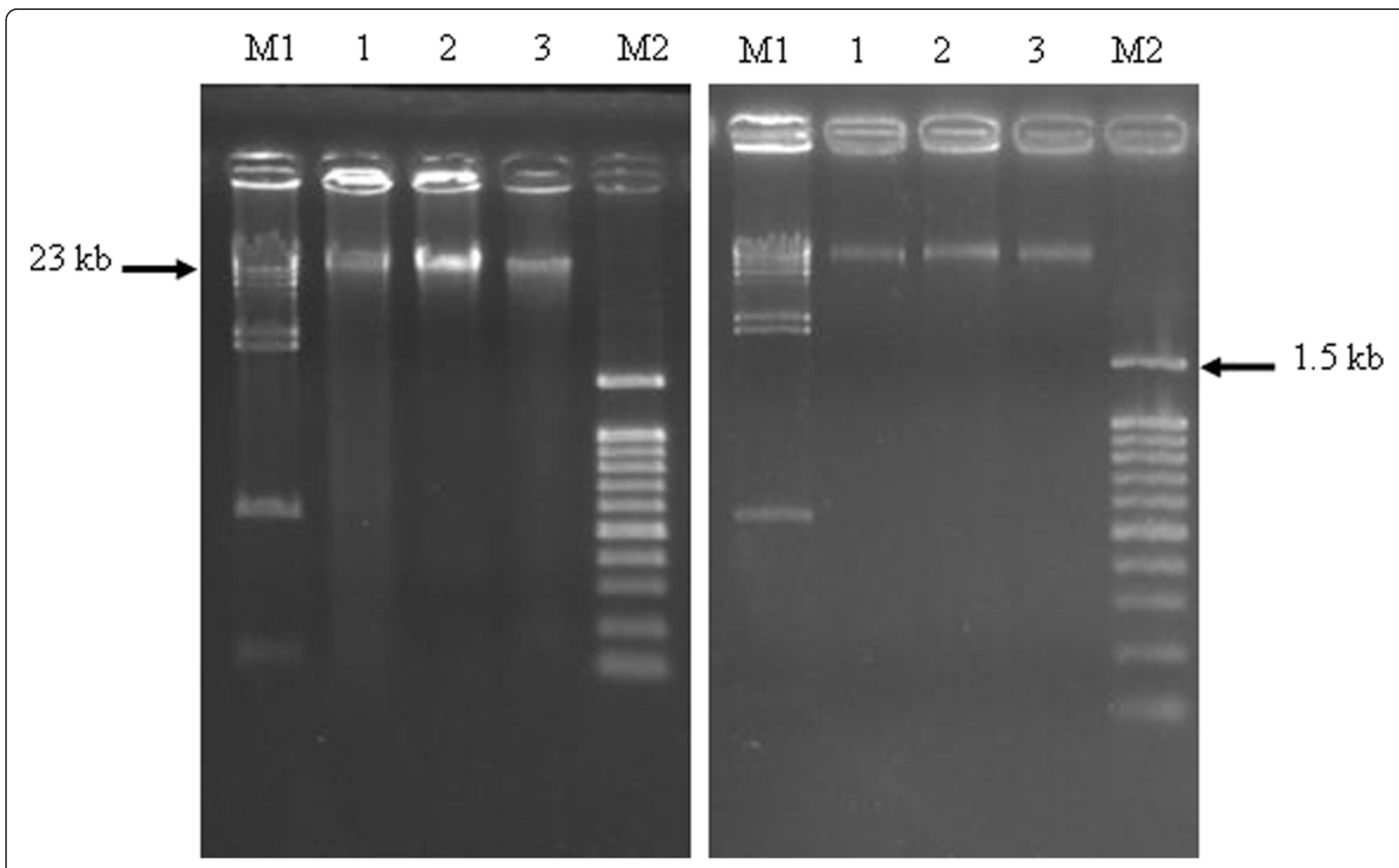

Figure 8 Agarose (1.8\% (w/v))-TBE gel electrophoresis of $1 \mu \mathrm{g}$ DNA (per lane) extracted from (A) SW620 and (B) Hs27 cells after $72 \mathrm{~h}$ in vitro culture in complete medium supplemented with (Lane 1) DMSO solvent only (control), (Lane 2) compound 1 (cardanol) at its $\mathrm{IC}_{50}$ value $(10.76 \mu \mathrm{g} / \mathrm{ml})$ and (Lane 3$)$ compound 2 (cardol) at its $\mathrm{IC}_{50}$ value $(\mathbf{3 . 0} \boldsymbol{\mu \mathrm { g }} / \mathrm{ml})$. Lanes M1 and M2 contain $\lambda$ Hind III and 100 bp ladders, respectively, as DNA size markers.

affected the SW620 cancer cells by necrosis, not by apoptosis, whereas they induced an antiproliferation response and not cell death in the Hs27 cells. In contrast, Vatansever et al. [54] reported that CEE from Turkey induced the death of the human breast cancer cell line (MCF-7) by the induction of apoptosis. Although the morphology of the MCF-7 cells was not visibly changed, the number of cells was decreased. In addition, whilst Umthong et al. [55] found that CWE and CME from Trigona laeviceps (stingless bee) in Samut Songkram province, Thailand, had a similar effect upon SW620 cells as that reported here (change in the cell morphology, loss of cell adhesion and cell death), in contrast, they found evidence of DNA fragmentation, unlike in this study with compounds 1 (cardanol) or 2 (cardol). Moreover, Chen et al. [56] reported that propolins A and B extracted from Taiwanese propolis could induce apoptosis of human melanoma A2058 cells, in addition to inducing the morphological changes in the cells, chromatin condensation and cell shrinkage. However, since we did not screen the crude extracts for changes in the cell morphology and DNA damage, but only the two purified compounds that were not propolin $A$ or $B$, then it is unclear if this represents the diversity of bioactivity within different propolis components or between propolis samples.

Cancer can be caused by the misregulation of, and so its treatment can be targeted at inhibition of, phosphatidylinositol-specific phospholipase C $\gamma 1$ (PI-PLC $\gamma 1$ ), since it plays a key role in the proliferation and progression of human cancer [57]. Thus, an inhibitor of PI-PLC $\gamma 1$ would be a useful tool for development of anticancer agents. Lee et al. [58] reported the isolation of a cardanol from the chloroform extract of Ginko biloba that exhibited inhibitory effects against PI-PLC $\gamma 1$ in a concentration-dependent manner. They also found that the structure of the cardanol could influence the inhibitory effect. Cardanol with unsaturated long carbon chains (cardanol $\mathrm{C}_{15: 1}$ and cardanol $\mathrm{C}_{17: 1}$ ) showed more potent activities than those with saturated long chains (cardanol $\mathrm{C}_{13: 0}$ and cardanol $\mathrm{C}_{15: 0}$ ). Other than the inhibition on PI-PLC $\gamma 1$, cardanol is reported to be cytotoxic in vitro to human cancer cell lines, such as HCT-15 (colon), MCF-7 (breast), A-549 (lung), HT-1197 (bladder) and SKOV-3 (ovary), but was not found to be cytotoxic to the normal colon cell line, CCD-18-Co.

In addition, Kubo et al. [59] reported that the cardol $\left(\mathrm{C}_{15: 0}\right)$ isolated from Anacardium occidentale was 
moderately cytotoxic to the murine B16-F10 melanoma cells in a dose-dependent manner with an $\mathrm{IC}_{50}$ value of $24 \mu \mathrm{M}(8.352 \mu \mathrm{g} / \mathrm{ml})$ and complete lethality at $40 \mu \mathrm{M}$ $(13.92 \mu \mathrm{g} / \mathrm{ml})$, which in terms of molarity is some twoto 3.5- fold higher than that observed here for compound 2 (cardol) from the Thai A. mellifera propolis (albeit subject to the caveat of on different cell lines). Since cardol is an amphipathic molecule, the cytotoxicity is potentially facilitated by its ability to act as a surfactant.

The two potentially new compounds isolated here from Thai A. mellifera propolis (a cardanol and a cardol) could be alternative antiproliferative agents for future development as anti-cancer drugs.

\section{Conclusion}

Propolis of A. mellifera was focused upon in this research due to the wide cultivated distribution of this bee species in Thailand, a floral biodiversity hotspot. The location of Nan province was accordingly selected due to the native and remote area of the country. Since the crude hexane and dichloromethane extracts of propolis provided a good in vitro antiproliferation/cytotoxicity against the selected cancer cell lines, it indicated that the polarity of the active compounds is likely to be low. Considering the cell line sensitivities and $\mathrm{IC}_{50}$ values for the antiproliferation/cytotoxicity before and after each fractionation, application of the active crude extracts is more interesting. After purification and chemical structure analysis, one member of each of the cardanol and cardol groups, as phenolic compounds, were revealed. The apparent absence of cytotoxicity of both compounds to the normal Hs27 cell line in vitro is of interest since many cancer drugs or chemotherapy agents used nowadays cause adverse side effects through being cytotoxic to normal cells. Considering the cell morphology, cell number and the cytotoxic effect, it is likely that both compounds affected the SW620 cancer cells by necrosis.

\footnotetext{
Acknowledgements

We wish to thank the National Research Council of Thailand; the Science for Locale Project under the Chulalongkorn University Centenary Academic Development Plan and the $90^{\text {th }}$ Anniversary of Chulalongkorn University Fund (Ratchadaphiseksomphot Endowment Fund); the Japan Society for the Promotion of Science; the Asahi Glass Foundation; the Thai Government Stimulus Package 2 (TKK2555), under the Project for the Establishment of a Comprehensive Center for Innovative Food, Health Products and Agriculture, the Ratchadapisek Somphot Endowment Fund; and the Higher Education Research Promotion and National Research University Project of Thailand (AS613A) for financial support. We also thank Dr. Robert Butcher for manuscript preparation. The helpful suggestions of two anonymous referees and the Editor are acknowledged.
}

\section{Author details}

${ }^{1}$ Department of Biology, Faculty of Science, Chulalongkorn University, 254 Phayathai Road, Bangkok 10330, Thailand. ${ }^{2}$ Department of Chemistry, Faculty of Science, Chulalongkorn University, 254 Phayathai Road, Bangkok, 10330, Thailand. ${ }^{3}$ Institute of Biotechnology and Genetic Engineering, Chulalongkorn University, 254 Phayathai Road, Bangkok 10330, Thailand. ${ }^{4}$ Honeybee Research Group, National Institute of Livestock and Grassland Science, Ibaraki 305-0901, Japan. ${ }^{5}$ Division of Applied Bioscience, Graduate School of Agriculture, Hokkaido University, Sapporo 060-8589, Japan. ${ }^{6}$ Department of Biology, Faculty of Science, Chulalongkorn University, 254 Phayathai Road, Bangkok 10330, Thailand.

\section{Authors' contributions}

DT performed the experiments. PP contributed to the study design, analyzed and interpreted the data. SP contributed to the invaluable help in cell culture. KK, MO, HM and AK contributed to invaluable suggestions and comments on research. CC did the design and supervision of the experiments. Also, she contributed in drafting the manuscript. All authors read the manuscript, contributed in correcting it and approved its final version.

\section{Competing interests}

The authors declare that they have no competing interests.

Received: 9 January 2012 Accepted: 30 March 2012

Published: 30 March 2012

\section{References}

1. Marcucci MC: Propolis: chemical composition, biological properties and therapeutic activity. Apidologie 1995, 26:83-99.

2. Papachristoforou A, Rortais A, Sueur J, Arnold G: Attack or retreat: contrasted defensive tactics used by Cyprian honeybee colonies under attack from hornets. Behav Process 2011, 86:236-241.

3. Kujumgiev A, Tsvetkova I, Serkedjieva Y, Bankova V, Christov R, Popov S: Antibacterial, antifungal and antiviral activity of propolis of different geographic origin. J Ethnopharmacol 1999, 64:235-240.

4. Mohammadzadeh S, Shariatpanahi M, Hamedi M, Ahmadkhaniha R, Samadi N, Ostad SN: Chemical composition, oral toxicity and antimicrobial activity of Iranian propolis. Food Chem 2007, 103:1097-1103.

5. Yang SZ, Peng LT, Su XJ, Chen F, Cheng YJ, Fan G, Pan SY: Bioassay-guided isolation and identification of antifungal components from propolis against Penicillium italicum. Food Chem 2011, 127:210-215.

6. Hegazi AG, Abd El Hady FK, Shalaby HA: An in vitro effect of propolis on adult worms of Fasciola gigantica. Vet Parasitol 2007, 144:279-286.

7. Ahn MR, Kumazawa S, Usui Y, Nakamura J, Matsuka M, Zhu F, Nakayama T: Antioxidant activity and constituents of propolis collected in various areas of China. Food Chem 2007, 101:1383-1392.

8. Banskota AH, Tezuka Y, Kadota S: Recent progress in pharmacological research of propolis. Phytother Res 2001, 15:561-571.

9. Carvalho AA, Finger D, Machado CS, Schmidt EM, Costa PM, Alves APNN, Morais TMF, de Queiroz MGR, Quinaia SP, da Rosa MR, dos Santos JMT, Pessoa C, de Moraes MO, Costa-Lotufo LV, Sawaya ACHF, Eberlin MN, Torres YR: In vivo antitumoural activity and composition of oil extract of Brazilian propolis. Food Chem 2011, 126:1239-1245.

10. Ghisalberti EL: Propolis: a review. Bee World 1979, 60:59-84.

11. Celli N, Mariani B, Dragani LK, Murzilli S, Rossi C, Rotilio D: Development and validation of a liquid chromatographic-tandem mass spectrometric method for the determination of caffeic acid phenethyl ester in rat plasma and urine. J Chromatogr B 2004, 810:129-136.

12. Burdock GA: Review of the biological properties and toxicity of bee propolis (propolis). Food Chem Toxicol 1998, 36:347-363.

13. Gardana C, Scaglianti M, Pietta P, Simonetti P: Analysis of the polyphenolic fraction of propolis from different sources by liquid chromatographytandem mass spectrometry. J Pharm Biomed Anal 2007, 45:390-399.

14. Valencia D, Alday E, Robles-Zepeda R, Garibay-Escobar A, Galvez-Ruiz JC, Salas-Reves M, Jimenez-Estrada M, Velazquez-Contreras E, Hernandez J, Velazquez C: Seasonal effect on chemical composition and biological activities of Soronan propolis. Food Chem 2012, 131:645-651.

15. Salatino A, Teixeira EW, Negri G, Message D: Origin and chemical variation of Brazilian propolis. eCAM 2005, 2:33-38.

16. Watanabe MAE, Amarante MK, Conti BJ, Sforcin JM: Cytotoxic constituents of propolis inducing anticancer effects: a review. J Pharm Pharmacol 2011, 63:1378-1386. 
17. Hernandez J, Goycoolea FM, Quintero J, Acosta A, Castañeda M, Dominguez Z, Robles R, Vazquez-Moreno L, Velazquez EF, Astiazaran $H_{\text {, }}$ Lugo E, Velazquez C: Sonoran propolis: chemical composition and antiproliferative activity on cancer cell lines. Planta Med 2007, 73:1469-1474

18. Jung BI, Kim MS, Kim HA, Kim D, Yang J, Her S, Song YS: Caffeic acid phenethyl ester, a component of beehive propolis, is a novel selective estrogen receptor modulator. Phytother Res 2010, 24:295-300.

19. Chen MJ, Chang WH, Lin CC, Liu CY, Wang TE, Chu CH, Shih SC, Chen YJ: Caffeic acid phenethyl ester induces apoptosis of human pancreatic cancer cells involving caspase and mitochondrial dysfunction. Pancreatol 2008, 8:566-576

20. Beltran-Ramirez O, Aleman-Lazarini L, Salcido-Neyoy M, Hernandez-Garcia S, Fattel-Fazenda S, Arce-Popoca E, Arellanes-Robledo J, Garcia-Roman R, Vazquez-Vazquez P, Sierra-Santoyo A, Villa-Trevino S: Evidence that the anticarcinogenic effect of caffeic acid phenethyl ester in the resistant hepatocyte model involves modifications of cytochrome P450. Toxicol Sci 2008, 104:100-106.

21. Jin UH, Song KH, Motomura M, Suzuki I, Gu YH, Kang YJ, Moon TC, Kim CH: Caffeic acid phenethyl ester induces mitochondria-mediated apoptosis in human myeloid leukemia U937 cells. Mol Cell Biochem 2008, 310:43-48.

22. Wu J, Omene C, Karkoszka J, Bosland M, Eckard J, Klein CB, Frenkel K: Caffeic acid phenethyl ester (CAPE), derived from a honeybee product propolis, exhibits a diversity of anti-tumor effects in pre-clinical models of human breast cancer. Cancer Lett 2011, 308:43-53.

23. Messerli SM, Ahn MR, Kunimasa K, Yanagihara M, Tatefugi T, Hashimoto $K$, Mautner V, Uto Y, Hori H, Kumazawa S, Kaji K, Ohta T, Maruta H: Artepillin C (ARC) in Brazilian green propolis selectively blocks oncogenic PAK1 signaling and suppresses the growth of NF tumors in mice. Phytother Res 2009, 23:423-427.

24. Sorimachi K, Nakamoto T: Alternative medicine safety: Agaricus blazei and propolis. Comb Chem High Throughput Screening 2011, 14:616-621.

25. Walgrave $S E$, Warshaw EM, Glesne LA: Allergic contact dermatitis from propolis. Dermatitis 2005, 16:209-215.

26. Aliboni A, D' Andrea A, Massanisso P: Propolis specimens from different locations of central Italy: chemical profiling and gas chromatographymass spectrometry (GC-MS) quantitative analysis of the allergenic ester benzyl cinnamate and benzyl salicylate. J Agr Food Chem 2011, 59:282-288.

27. Umthong $S$, Phuwapraisirisan $P$, Puthong $S$, Chanchao C: In vitro antiproliferative activity of partially purified Trigona laeviceps propolis from Thailand on human cancer cell lines. BMC Complement Altern Med 2011, 11:37.

28. Najafi MF, Vahedy F, Seyyedin M, Jomehzadeh HR, Bozary K: Effect of the water extracts of propolis on stimulation and inhibition of different cells. Cytotechnology 2007, 54:49-56.

29. Santos FA, Bastos EMA, Uzeda M, Carvalho MAR, Farias LM, Moreira ESA, Braga FC: Antibacterial activity of Brazilian propolis and fractions against oral anaerobic bacteria. J Ethnopharmacol 2002, 80:1-7.

30. Liberio SA, Pereira AL, Dutra RP, Reis AS, Araujo MJ, Mattar NS, Silva LA, Ribeiro MNS, Nascimento FRF, Guerra RNM, Monteiro-Neto V: Antimicrobial activity against oral pathogens and immunomodulatory effects and toxicity of geopropolis produced by the stingless bee Melipona fasciculata Smith. BMC Complement Altern Med 2011, 11:108.

31. Massaro FC, Brooks PR, Wallace HM, Russell FD: Cerumen of Australian stingless bees (Tetragonula carbonaria): gas chromatography-mass spectrometry fingerprints and potential anti-inflammatory properties. Naturwissenschaften 2011, 98:329-337.

32. Bonvehi JS, Gutierrez $L$ : The antimicrobial effects of propolis collected in different regions in the Basque Country (Northern Spain). World I Microb Biot 2011, published on line doi: 10.1007/s11274-011-0932-y.

33. Castro ML, Nascimento AM, Ikegaki M, Costa-Neto CM, Alencar SM, Rosalen PL: Identification of a bioactive compound isolated from Brazilian propolis type 6. Bioorg Med Chem 2009, 17:5332-5335.

34. Miguel MG, Nunes S, Dandlen SA, Cavaco AM, Antunes MD: Phenols and antioxidant activity of hydro-alcoholic extracts of propolis from Algarve, South of Portugal. Food Chem Toxicol 2010, 48:3418-3423.

35. Takemura T, Urushisaki T, Fukuoka M, Hosokawa-Muto J, Hata T, Okuda Y, Hori S, Tazawa S, Araki Y, Kuwata K: 3, 4-dicaffeoylquinic acid, a major constituent of Brazilian propolis, increases TRAIL expression and extends the lifetimes of mice infected with the influenza A virus. eCAM 2012, published on line doi:10.1155/2012/946867.

36. Przeworska E, Gubernator J, Kozubek A: Formation of liposomes by resorcinolic lipids, single-chain phenolic amphiphiles from Anacardium occidentale L. BBA-Biomembranes 2001, 1513:75-81.

37. Stasiuk M, Kozubek A: Biological activity of phenolic lipids. Cell Mol Life Sci 2010, 67:841-860.

38. Trevisan MTS, Pfundstein B, Haubner R, Würtele G, Spiegelhalder B, Bartsch H, Owen RW: Characterization of alkyl phenols in cashew (Anacardium occidentale) products and assay of their antioxidant capacity. Food Chem Toxicol 2006, 44:188-197.

39. Gellerman JL, Anderson WH, Schlenk H: Synthesis of anacardic acids in seeds of Ginkgo biloba. BBA-Lipid Lipid Met 1976, 431:16-21.

40. Kubo J, Lee JR, Kubo I: Anti-Helicobacter pylori agents from the cashew apple. J Agr Food Chem 1999, 47:533-537.

41. Lee SJ, Park WH, Hi M: Bioassay-guided isolation of antiplasmodial anacardic acids derivatives from the whole plants of Viola websteri Hemsl. Parasitol Res 2009, 104:463-466.

42. Kubo I, Masuoka N, Ha TJ, Tsujimoto K: Antioxidant activity of anacardic acids. Food Chem 2006, 99:555-562

43. Aguilar-Ortigoza CJ, Sosa V, Aguilar-Ortigoza M: Toxic phenols in various Anacardiaceae species. Econ Bot 2003, 57:354-364.

44. Szliszka E, Czuba ZP, Bronikowska J, Mertas A, Paradysz A, Wojciech K: Ethanol extract of propolis augments TRAIL-induced apoptotic death in prostate cancer cells. eCAM 2009, published on line doi: 10.1093/ecam/ nep 180

45. Wang D, Xiang DB, He YJ, Li ZP, Wu XH, Mou JH, Xiao HL, Zhang QH: Effect of caffeic acid phenethyl ester on proliferation and apoptosis of colorectal cancer cells in vitro. World J Gastroentero 2005, 11:4008-4012.

46. Kuo HC, Kuo WH, Lee YJ, Lin WL, Chou FP, Tseng TH: Inhibitory effect of caffeic acid phenethyl ester on the growth of $C_{6}$ glioma cells in vitro and in vivo. Cancer Lett 2006, 234:199-208.

47. Chen $J H$, Shao Y, Huang MT, Chin CK, Ho CT: Inhibitory effect of caffeic acid phenethyl ester on human leukemia HL-60 cells. Cancer Lett 1996, 108:211-214

48. Lee YJ, Liao PH, Chen WK, Yang CC: Preferential cytotoxicity of caffeic acid phenethyl ester analogues on oral cancer cells. Cancer Lett 2000, 153:51-56.

49. Jin UH, Chung TW, Kang SK, Suh SJ, Kim JK, Chung KH, Gu YH, Suzuki I, Kim CH: Caffeic acid phenyl ester in propolis is a strong inhibitor of matrix metalloproteinase-9 and invasion inhibitor: Isolation and identification. Clin Chim Acta 2005, 362:57-64

50. Hu F, Li Y, Chen M, Xuan H: Effects of encapsulated propolis on blood glycemic control, lipid metabolism and insulin resistance in type 2 diabetes mellitus rats. eCAM 2012, published on line doi: 10.1155/2012/ 981896.

51. Ramanauskiene $\mathrm{K}$, Zilius M, Briedis V: A study on release of propolis extract components from emulsion-type dispersion. Medicina 2011, 47:354-359.

52. Awale S, Li F, Onozuka H, Esumi H, Tezuka Y, Kadota S: Constituents of Brazilian red propolis and their preferential cytotoxic activity against human pancreatic PANC-1 cancer cell line in nutrient-deprived condition. Bioorg Med Chem 2008, 16:181-189.

53. Wang W, Abbruzzese JL, Evans DB, Callery MP: The nuclear factor-kappa B RelA transcription factor is constitutively activated in human pancreatic adenocarcinoma cells. Clin Cancer Res 1999, 5:119-127.

54. Vatansever HS, Sorkun K, Gurhan SD, Ozdal-Kurt F, Turkoz E, Gencay O, Salih B: Propolis from Turkey induces apoptosis through activating caspases in human breast carcinoma cell lines. Acta Histochem 2010 112:546-556

55. Umthong S, Puthong S, Chanchao C: Trigona laeviceps propolis from Thailand: antimicrobial, antiproliferative and cytotoxic activities. Am J Chin Med 2009, 37:855-865.

56. Chen $\mathrm{CN}, \mathrm{Wu} \mathrm{CL}$, Lin JK: Apoptosis of human melanoma cells induced by the novel compounds, propolin A and propolin B, from Taiwanese propolis. Cancer Lett 2007, 245:218-231.

57. Hill SR, Bonjouklian R, Powis G, Abraham RT, Ashendel CL, Zalkow LH: A multisample assay for inhibitors of phosphatidylinositol phospholipase C: identification of naturally occurring peptide inhibitors with antiproliferative activity. Anti-Cancer Drug Des 1994, 9:353-361. 
58. Lee JS, Cho YS, Park EJ, Kim J, Oh WK, Lee HS, Ahn JS: Phospholipase CY1 inhibitory principles from the Sacrotestas of Ginkgo biloba. J Nat Prod 1998, 61:867-871.

59. Kubo I, Nitoda T, Tocoli FE, Green IR: Multifunctional cytotoxic agents from Anacardium occidentale. Phytother Res 2011, 25:38-45.

\section{Pre-publication history}

The pre-publication history for this paper can be accessed here: http://www.biomedcentral.com/1472-6882/12/27/prepub

doi:10.1186/1472-6882-12-27

Cite this article as: Teerasripreecha et al: In vitro antiproliferative/ cytotoxic activity on cancer cell lines of a cardanol and a cardol enriched from Thai Apis mellifera propolis. BMC Complementary and Alternative Medicine 2012 12:27.

Submit your next manuscript to BioMed Central and take full advantage of:

- Convenient online submission

- Thorough peer review

- No space constraints or color figure charges

- Immediate publication on acceptance

- Inclusion in PubMed, CAS, Scopus and Google Scholar

- Research which is freely available for redistribution

Submit your manuscript at www.biomedcentral.com/submit 